\title{
AN INTRODUCTION TO SAN VICENTE (CHICHONTEPEC) VOLCANO, EL SALVADOR
}

\author{
Rotolo S.G. ${ }^{* 1}$, Aiuppa A. ${ }^{1}$, Pullinger C. R. ${ }^{2}$,Parello F. ${ }^{1}$, Tenorio-Mejia J. ${ }^{3}$ \\ 1) Dipartimento di Chimica e Fisica della Terra (C.F.T.A.), \\ Via Archirafi 36, 90123 Palermo, ITALY \\ 2) Department of Geological Engineering and Sciences, Michigan Technological \\ University, 1400 Townsend Drive, Houghton, Michigan 49931, U.S.A. \\ 3) Comision Ejecutiva Hidroeléctrica del Rio Lempa (CEL), 49 Avenida Norte, \\ San Salvador, El Salvador \\ * Corresponding Author; e-mail: hauser@mbox.unipa.it
}

(Recibido 30/3/1998; Aceptado 29/5/1998)

\begin{abstract}
San Vicente is a composite volcano whose oldest volcanic events (2.2 Ma) are recorded in the western sector, where the remnants of the older La Carbonera edifice outcrop. This volcanic center, which produced mildly tholeiitic to transitional lavas, collapsed during a plinian eruption, giving rise to the formation of a partially preserved caldera (La Carbonera caldera). The renewal of volcanic activity started with clearly calc-alkaline lavas, mostly twopyroxene andesites, that built up the San Vicente volcanic edifice. Crystal fractionation had primary control on magma evolution.

The event that triggered the caldera forming plinian eruption is still uncertain; we have some textural evidences of mixing/mingling with more mafic magmas, but this process seems to be delimited to few samples. A major role could have been played by the tectonic instability related to the first stages of central graben opening.
\end{abstract}

RESUMEN: Durante 1993 un equipo de investigadores italianos y salvadoreños realizó investigaciones en el volcán de San Vicente, El Salvador, con el objetivo de definir la evolución petrológica y volcánica de dicho centro volcánico. Estos estudios formaron parte de estudios preliminares de geotermia en el área. Los productos volcánicos más antiguos (2,2 M.a.) se encuentran en el sector occidental del volcán de San Vicente, en donde afloran los depósitos de la estructura volcánica La Carbonera. Este centro volcánico, el cuál produjo lavas medianamente toleíticas a transicionales, colapsó posterior a una erupción pliniana y formó una caldera preservada parcialmente y definida como La Carbonera. La actividad volcánica se reanuda con la producción de lavas calco-alcalinas, en su mayoria andesitas de dos piroxenos. El proceso magmático principal es el de fraccionamiento de cristales. El evento que causó la erupción pliniana es todavia desconocido. Tenemos cierta evidencia textural de "mixing/mingling" de magmas, pero esto sólo se observa en algunas muestras. La inestabilidad tectónica del área debido a la formación del graben central de El Salvador pudo haber tenido un papel muy importante como causa de la erupción. 


\section{INTRODUCTION}

During 1993 efforts were made by an italian-salvadorian team to investigate San Vicente volcano, El Salvador. Geothermal exploration in the San Vicente geothermal field started in 1965 with a reconnaissance geological survey done by CEL. After the first promising results, research continued with the drilling of a deep exploration well (SV-1) and two shallow ones (PESV-1 and PESV-2). The area seemed to be particularly promising for exploitation and energy production, since a hot $\left(\mathrm{T}>250{ }^{\circ} \mathrm{C}\right)$ permeable layer was drilled through at a relatively low depth (1200-1300 m). Recent studies on fluid geochemistry (CEL, 1992; Aiuppa et al.,1997) confirmed the hydraulic continuity between the superficial thermal manifestations and the geothermal reservoir, allowing also a better evaluation of its extension.

The area had been previously described by Meyer-Abich (1956) and in an earlier study Williams \& Meyer-Abich (1955) studied the Apastepeque volcanic field just northeast of the San Vicente volcanic field.

The aim of this project, was to develop a deeper knowledge of the geological structure of the volcano in order to contribute to CEL's geothermal exploration and development projects in the area. In this paper, a preliminary account of the volcanological history, petrology, and magmatic evolution of the San Vicente volcanic complex is given.

\section{GEOLOGY AND STRATIGRAPHY}

San Vicente, also known as Chichontepec, is the second most voluminous volcano in $\mathrm{El}$ Salvador $\left(130 \mathrm{~km}^{3}\right)$, after Santa Ana volcano which has a volume of $265 \mathrm{~km}^{3}$ (Carr et al., 1981). It is located approximately $50 \mathrm{~km}$ east of the capital city, San Salvador, and shadows the city of San Vicente (population 100,000) which lies on its northeastern slopes. The edifice (Fig. 1) rises inside the Central Graben structural depression, a late-Pliocene extensional structure (20 to $30 \mathrm{~km}$ wide) that runs along the length of
El Salvador in a WNW-ESE direction. The graben cuts through a Tertiary volcanic basement which locally consists of basalt and andesite lavas, tuffs, agglomerates, and diatomite deposits that reflect a prehistoric lake (Carr, 1976; Carr \& Stoiber 1977; Carr et al. 1981; Pichler \& Weyl, 1973; Wiesemann, 1975; Williams \& Meyer-Abich, 1955).

Chichontepec is a densely vegetated paired stratovolcano with summit craters aligned roughly in an E-W direction. Based on morphology, the eastern crater (elevation 2180 m) appears to be the most recent, while the western crater (elevation $2105 \mathrm{~m}$ ) appears older. Thick ( 20 m), lobate lava flows which probably were emitted from a central vent are observed on the north and south flanks. The eastern flank is also characterized by thick lobate lava flows which were emitted from a parasitic vent aligned in an almost E-W direction with both summit craters. There is no evidence of historical eruptions. However, its youngest products are covered by the AD 260 Tierra Blanca tephra emitted from the nearby Ilopango volcano (Hart \& Steen-Mcintyre, 1983). Its present day state is that of solfatara-type activity, characterized by low temperature fumaroles and hot springs, which are located on the northern and western flanks of the volcano (Aiuppa et al. 1997). The summit craters do not present any fumarolic activity. West of the main volcanic edifice is a semicircular structure, which in this work will be designated La Carbonera. It consists of a series of pronounced hills arranged in a semicircle. Small hills, west and south of the main Chichontepec volcanic edifice represent uncovered remnants of tertiary basement rocks. The Nahuistepe domes which lie approximately $12 \mathrm{~km}$ southwest of the Chichontepec summit represent an older magmatic period probably unrelated to the present one.

Evidence of faulting in the San Vicente volcanic complex is limited to those areas that have not been covered by the San Vicente volcano and Ilopango caldera recent deposits. The most pronounced faulting is observed just north of the volcano, where a series of E-W trending faults form a large scarp with 


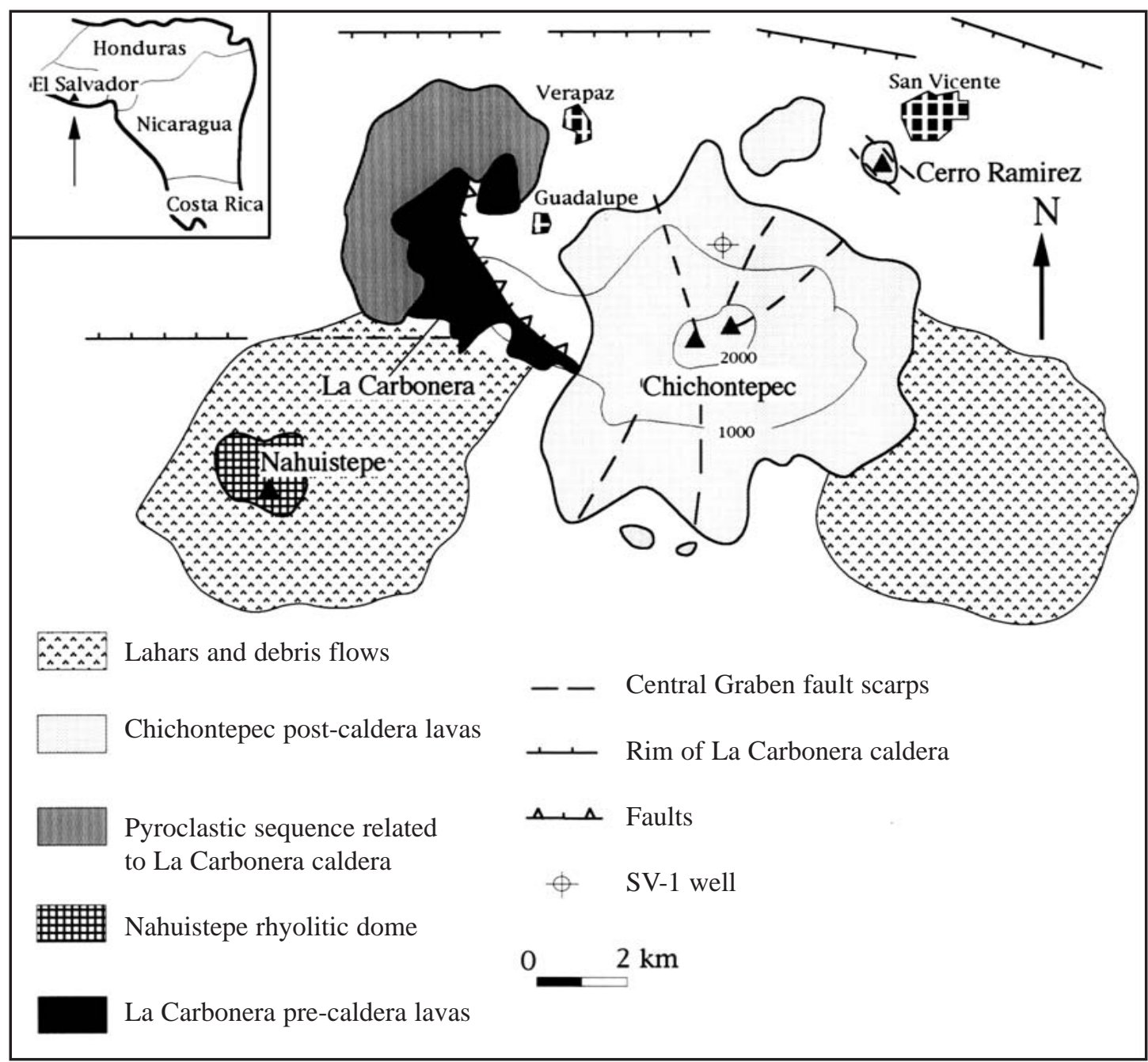

Fig 1: Generalized map of the San Vicente volcanic area.

displacements of up to $300 \mathrm{~m}$. These faults represent the northern margin of the Central Graben, while the southern margin is represented by a series of faults that extend eastwards from lake Ilopango through $\mathrm{La}$ Carbonera and in the process aligns the summit craters. A series of NW-SE faults are also observed in older deposits west of Chichontepec volcano and in Cerro Ramirez, 1 $\mathrm{km}$ southwest of the city of San Vicente. Northerly trending faults control the location of the major fumarolic areas on the northern flank of Chichontepec.
Previous field and petrological studies recognized the existence of a multistage evolution of the San Vicente volcanic area (Aiuppa et al., in preparation; Barberi et al., 1995; Rotolo \& Castorina, in press). The most important stages and events in the history of the volcano are described below.

\section{Pre-caldera stage: La Carbonera} (CARB) lava flows

This stage is characterized by the effusive activity of a volcanic center, whose remnants actually form an annular structure of cinder 
cones and lava flows, outcropping around $\mathrm{La}$ Carbonera hill (El Cimarron, La Carbonera and El Volcancito hills; Fig. 3).

During this phase, mildly tholeiitic to transitional lavas, ranging from high alumina basalts to andesites, were produced. Preliminary $\mathrm{K} / \mathrm{Ar}$ ages (Table 1) give a quite wide time span, from 2.2 to $1.2 \mathrm{Ma}$, indicating that this volcanic centre was active long before the opening of the Central Graben.

Table 1

$\mathrm{K} / \mathrm{Ar}$ age determinations on whole rock and plagioclase fractions

\begin{tabular}{lcccccc}
\hline Sample & $\begin{array}{c}\text { Rock } \\
\text { type }\end{array}$ & Group & Material & K(wt\%) & 40 Ar* & Age (Ma) \\
SVN 14 & hab & CARB & w.r. & 0.448 & 0.90 & $1.2 \pm 0.2$ \\
SVN 98 & hab & CARB & w.r. & 0.448 & 1.72 & $2.2 \pm 0.4$ \\
SVN 85 & rhy & NAU & plg & 0.378 & 1.12 & $1.7 \pm 0.3$
\end{tabular}

Decay constants: $\lambda \varepsilon+\lambda^{\prime} \varepsilon=0.581 * 10^{-10} \mathrm{yr}^{-1} ; \lambda \beta=4.962 *$ $10^{-10} \mathrm{yr}^{-1}$

${ }^{40} \mathrm{~K} / \mathrm{K}_{\text {total }}=1.193 * 10^{-4} ;{ }^{40} \mathrm{Ar} *$ refers to radiogenic Argon $\left(10^{-12} \mathrm{~mol} / \mathrm{g}\right)$. hab = high alumina basalt; rhy = rhyolite; w.r. $=$ whole rock; $p l g=$ plagioclase. activity

Caldera stage: La Carbonera plinian

CARB effusive activity was abruptly interrupted by an explosive phase that produced a pyroclastic sequence that outcrops mostly in the northwestern sector of San Vicente volcanic area (Fig. 1). In the southwestern sector the few sections that have been found are highly condensed and heavily reworked by postdepositional processes. A clay rich lahar deposit covers an approximate area of $20 \mathrm{~km}^{2}$ on the southwestern flanks of La Carbonera, reaching as far south as the Nahuistepe domes. The lahar overlies the CARB tephras.

Ignimbrite deposits, referred to as BI (Aiuppa et al., in preparation), overlie CARB lavas and mark the beginning of the pyroclastic sequence (Fig. 2). Meyer (1967) reports other large volumes of ignimbrites of the same age in El Salvador, which can also be related to explosive volcanic activity associated with the opening of the Central Graben. This deposit is composed of a brownish yellow, poorly welded, chaotic mix of ash matrix, with pumice fragments and less abundant lithic lapilli.

The maximum measured thickness is 10 $\mathrm{m}$. BI unit is separated from the overlying deposits by a two meter thick brown-colored paleosol, containing volcanoclastic fragments. It indicates that a considerable time span occurred

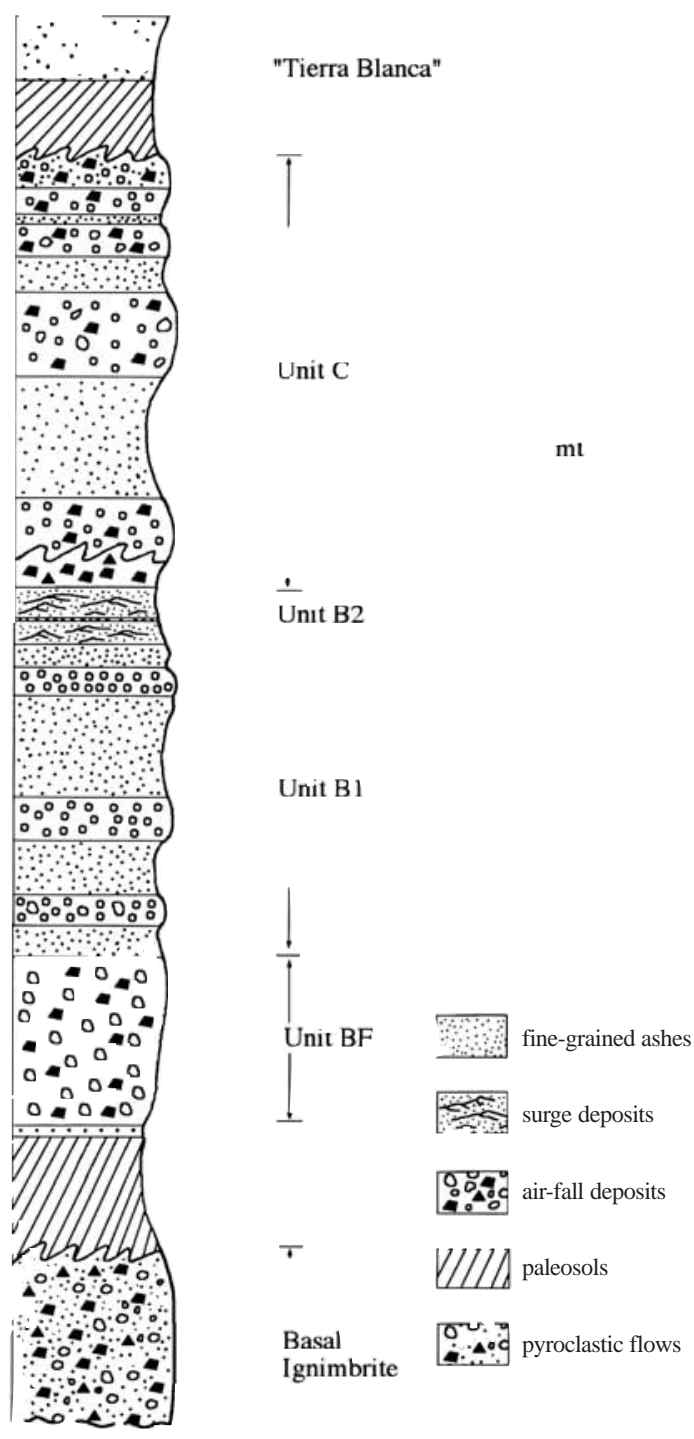

Fig 2: Stratigraphic column of the pyroclastic sequence interposed between pre-caldera and post-caldera lava flows. See text for description of Units. 
between the BI ignimbrite and overlying tephras.

The same paleosol is followed by a dacitic fallout pumice deposit, whose thickness varies from 0.6 to $1.3 \mathrm{~m}$. This unit, hereafter called Basal Fall (BF), indicates the onset of a plinian phase characterized by a substained column. It is mainly composed of pumice lapilli (rounded to sub-angular, white-grey colored and highly vesiculated, with elongated subparallel vesicles) with minor lithic fragments of unaltered basalticandesitic lava fragments and hydrothermally altered rocks in the phyllitic-propylitic facies. The $\mathrm{BF}$ unit is a relatively homogeneous unit, except for changes in gradation from reverse to direct, and the upward increase in lithics relatively to pumice. BF unit was used as a stratigraphic marker bed and an isopach map of this unit (Fig. 3) locates the vent position inside the annular structure outlined by $\mathrm{La}$
Carbonera - Cerro El Cimarron - Cerro El Volcancito cinder and lava cones.

The BF deposits, whose estimated volume are $1.5-2 \mathrm{~km}^{3}$, shows an elliptical distribution pattern with a NNE-SSW axis. Unit B1, that overlies the basal fall, consists of alternating coarse pumice-fall fragments with minor lithics, and brown ash deposits with no internal structures. The contacts between these are generally sharp. This deposit is likely to be related to fluctuations in energy and height of the plinian column, and to the beginning of the collapse itself, as recorded in some sections by ash-flow pyroclastic deposits (i.e. the brown ashes containing pumice and lithic fragments).

B2 unit is a pyroclastic surge deposit containing ash-sized particles whose total thickness ranges from 0.2 to $0.8 \mathrm{~m}$. This grey to

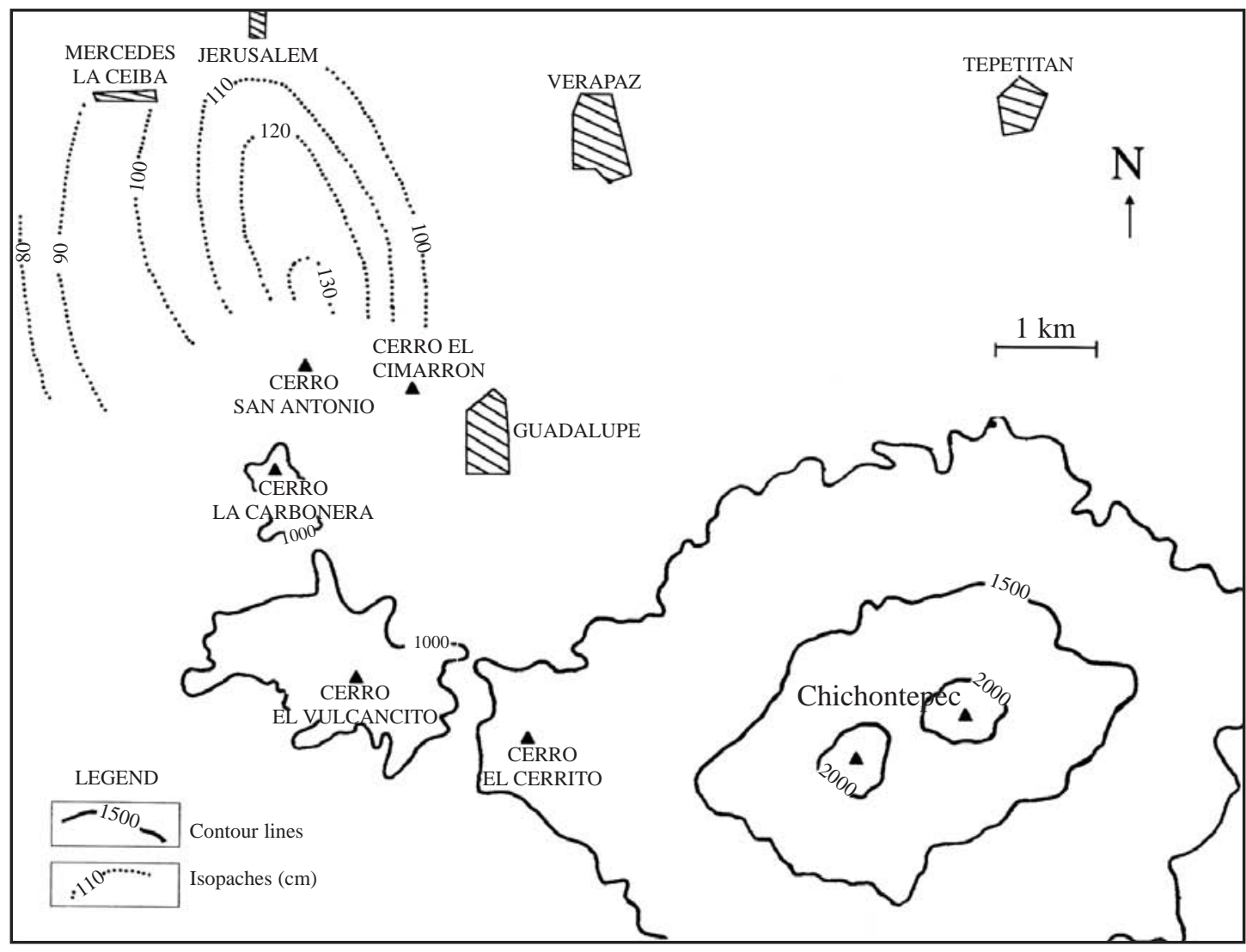

Fig 3: Isopach map for Basal Fall (BF) deposit. The NNE-SSW axis suggests a vent location inside La Carbonera Caldera, whose remnants crop out from Cerro El Cimarron to Cerro El Vulcancito. 
violet colored deposit, made of well-developed plane-parallel beds (about $0.1 \mathrm{~m}$ thick) containing gas bubbles and accretionary lapilli, is the result of magma-water interaction in a confined aquifer inside the volcanic edifice. The presence of this hydrothermal system is also confirmed by propylitic alteration on lithic fragments.

This Unit is cut at its top by an erosional surface which, in turn, is overlaid by a third pyroclastic deposit, Unit C. It records a less complete volcanic cycle and is composed, similarly to unit B1, of a sequence of alternating coarse grained layers of pumice and lithic fragments with ash layers. The former are normally graded deposits, mainly composed of white, well-vesiculated pumice and less abundant lithic fragments; the latter are brown colored and they do not show any internal structure. Unit $\mathrm{C}$ was deposited during a more recent plinian phase, and is covered by $2 \mathrm{~m}$ thick paleosol. The explosive phases partially recorded by the deposits described above led to the collapse of the La Carbonera Volcanic complex and to the formation of the La Carbonera caldera.

Table 2

Petrographic characters of pre- and post-caldera lavas

\begin{tabular}{lcc}
\hline & $\begin{array}{c}\text { Pre-caldera } \\
\text { (CARB) }\end{array}$ & $\begin{array}{c}\text { Post-caldera } \\
\text { (CHI) }\end{array}$ \\
\hline $\begin{array}{l}\text { Mean An \% } \\
\text { (core - rim) } \\
\text { of plg phenocrysts }\end{array}$ & $93-77$ & $\begin{array}{r}52-71 \text { (reversed zoning) } \\
52-47 \text { (normal zoning) }\end{array}$ \\
$\begin{array}{l}\text { Range An \% of plg } \\
\text { microphenocryst }\end{array}$ & 62 to 55 & 57 to 75 \\
$\begin{array}{l}\text { Mean En \% } \\
\text { (core - rim) } \\
\text { of opx phenocrysts }\end{array}$ & $68-59$ & $62-70$ (reversed zoning) \\
$\begin{array}{l}\text { Range En \% of opx } \\
\text { microphenocrysts }\end{array}$ & 60 to 53 & 63 - 59 (normal zoning) \\
Olivine & & 67 to 56 \\
Hornblende & aften present & quite rarely present \\
& & present from \\
& & $\mathrm{SiO}_{2}>63 \%$ \\
\hline
\end{tabular}

Post-caldera stage: Chichontepec (CHI) lava flows.

The renewal of volcanic activity after the pyroclastic phases formed a considerable volume $\left(130 \mathrm{~km}^{3}\right)$ of two-pyroxene andesites, building up the Chichontepec edifice inside the caldera formed by the collapse of La Carbonera edifice. Small volumes of block and ash pyroclastic flow deposits, interposed between andesitic lavas, are probably connected to low-volume dome collapse events. The lowest slopes of the volcano, particularly the southeastern sector, are covered by lahar and block and ash deposits that form a fan-type shape of roughly $80 \mathrm{~km}^{2}$ and controls the morphology and drainage patterns of the terrain; one small lahar occurred in the rainy season of 1995, travelling approximately $8 \mathrm{~km}$ south, from an elevation of about $1500 \mathrm{~m}$ and causing limited damage.

\section{PETROGRAPHY}

Pre-caldera lavas - The CARB group is generally composed of porphyritic, pilotaxitic lavas, containing phenocrysts of plagioclase (mostly), olivine, clinopyroxene and magnetite set in a black microcrystalline matrix.

The most characteristic samples inside this group are the low-MgO $(<5 \mathrm{wt} \%)$ and highalumina basalts (HAB). Olivine phenocrysts have a composition in the range $\mathrm{Fo}_{74-80}$; resorption or pigeonite rims are frequently observed. Plagioclase is very abundant, up to 70 vol\% in HAB; anorthite phenocrysts are typically $\mathrm{An}_{89-93}$, while groundmass plagioclase has a composition that ranges from $\mathrm{An}_{55}$ to $\mathrm{An}_{62}$ (Table 2). CARB plagioclases show normal zoning patterns: cores are An rich compared to rims and rims are richer in An content than microlites. Augite phenocrysts $\left(\mathrm{Wo}_{33-36} \mathrm{En}_{40}\right.$ $\mathrm{Fs}_{23-25}$ ) are common, while pigeonite is found in the groundmass. The presence of pigeonite is peculiar of CARB lavas. Orthopyroxene is very rare, being present only in the most evolved samples $\left(\mathrm{Wo}_{3} \mathrm{En}_{59} \mathrm{Fs}_{37}\right)$, while amphibole is completely absent. 
La Carbonera tephra - Petrographic observations of these deposits, show that: (i) Basal Fall pumices are characterized by the presence of brown hornblende, being completely absent in the other levels; (ii) pyroxene abundance decreases steadily towards the top of the column; (iii) content of phenocrysts decreases abruptly in the higher Unit (C Unit), plagioclase being the sole phenocryst phase.

Post-caldera lava flows: all post-caldera lavas are highly porphyritic, containing phenocrysts of plagioclase, orthopyroxene, clinopyroxene, $( \pm$ hornblende) and magnetite, set in a grey, glassy to microcrystalline matrix. The distinguishing feature of these is the abundance of glomerophyric crystal clots, microgranular enclaves and coarse grained anorthositic xenoliths.

Olivine is very rare and, when present, is almost completely resorbed. Complexely zoned plagioclase megacrystals (up to $4 \mathrm{~mm}$ ) with calcic cores $\left(\mathrm{An}_{65-70}\right)$ and very complex zoning patterns, are quite frequent. The peculiar characters are dusty cores and sieved rims, either by rhyolitic glass or by fine grained matrix material. Groundmass plagioclase have compositions of $\mathrm{An}_{57-75}$. It is important to note that often microphenocrysts are enriched in the An component compared to phenocrysts, and in turn phenocryst rims are anorthite-richer compared to cores. Orthopyroxene phenocrysts have a composition in the range $\mathrm{Wo}_{2-3} \mathrm{En}_{62-73}$

Table 3

Whole roch analyses of lava pre- and post-caldera lava flows (modified from Rotolo \& Castorina, in press). Major and trace elements by XRF on pressed powder pellets using the analytical procedures of Franzini et al. (1975); LOI determined by heating at $1050{ }^{\circ} \mathrm{C}$ for two hours. $\mathrm{Na} 2 \mathrm{O}$ and $\mathrm{MgO}$ were determined by AES and AAS, respectively.

\begin{tabular}{|c|c|c|c|c|c|c|c|c|c|c|c|}
\hline Sample & SVN 14 & SVN 73 & SVN 79 & SVN 98 & SVN 163 & SVN 85 & SVN 1 & SVN 36 & SVN 43 & SVN 117 & SVN 122 \\
\hline Group & CARB & CARB & CARB & CARB & CARB & NAU & CHI & $\mathrm{CHI}$ & CHI & CHI & CHI \\
\hline $\mathrm{SiO}_{2}$ & 50.81 & 66.86 & 58.71 & 50.49 & 54.99 & 73.48 & 61.29 & 64.09 & 58.58 & 56.11 & 59.00 \\
\hline $\mathrm{TiO}_{2}$ & 0.86 & 0.65 & 0.70 & 0.81 & 1.01 & 0.23 & 0.53 & 0.52 & 0.65 & 0.80 & 0.59 \\
\hline $\mathrm{Al}_{2} \mathrm{O}_{3}$ & 22.14 & 15.51 & 18.19 & 21.83 & 18.62 & 14.41 & 17.09 & 16.63 & 18.69 & 18.95 & 18.28 \\
\hline FeOtot & 7.95 & 4.39 & 6.77 & 8.16 & 8.83 & 2.10 & 5.37 & 5.05 & 6.48 & 7.43 & 6.45 \\
\hline $\mathrm{MnO}$ & 0.15 & 0.11 & 0.16 & 0.15 & 0.18 & 0.02 & 0.13 & 0.11 & 0.15 & 0.16 & 0.15 \\
\hline $\mathrm{MgO}$ & 3.62 & 0.81 & 2.82 & 4.44 & 2.83 & 0.25 & 3.53 & 1.98 & 3.49 & 3.51 & 3.23 \\
\hline $\mathrm{CaO}$ & 9.41 & 3.30 & 6.21 & 9.26 & 7.05 & 2.03 & 5.64 & 4.63 & 6.95 & 7.38 & 6.65 \\
\hline $\mathrm{Na}_{2} \mathrm{O}$ & 3.07 & 4.84 & 4.24 & 3.02 & 3.98 & 4.22 & 3.63 & 3.47 & 3.51 & 3.50 & 3.49 \\
\hline $\mathrm{K}_{2} \mathrm{O}$ & 0.51 & 1.94 & 1.16 & 0.50 & 0.89 & 3.14 & 1.29 & 1.79 & 1.19 & 0.98 & 1.13 \\
\hline $\mathrm{P}_{2} \mathrm{O}_{5}$ & 0.16 & 0.25 & 0.29 & 0.17 & 0.30 & 0.02 & 0.16 & 0.19 & 0.13 & 0.16 & 0.15 \\
\hline LOI & 0.94 & 0.95 & 0.50 & 0.73 & 0.96 & 0.03 & 1.04 & 1.16 & 0.66 & 0.87 & 0.72 \\
\hline $\mathrm{Mg} \#$ & 44.8 & 24.7 & 42.6 & 49.2 & 36.3 & 17.6 & 54.0 & 41.1 & 48.3 & 45.7 & 47.2 \\
\hline V & 296 & 31 & 108 & 277 & 225 & 19 & 131 & 124 & 171 & 198 & 157 \\
\hline $\mathrm{Cr}$ & 15 & 3 & 8 & 15 & 11 & 2 & 7 & 9 & 10 & 11 & 8 \\
\hline Co & 28 & 11 & 22 & 31 & 31 & 0 & 19 & 16 & 23 & 26 & 24 \\
\hline $\mathrm{Ni}$ & 7 & 3 & 6 & 10 & 5 & 2 & 4 & 4 & 6 & 4 & 6 \\
\hline $\mathrm{Rb}$ & 10 & 40 & 23 & 10 & 15 & 65 & 27 & 38 & 27 & 23 & 29 \\
\hline $\mathrm{Sr}$ & 539 & 362 & 89 & 544 & 512 & 160 & 368 & 383 & 415 & 541 & 382 \\
\hline $\mathrm{Y}$ & 16 & 37 & 23 & 18 & 18 & 15 & 18 & 30 & 20 & 20 & 19 \\
\hline $\mathrm{Zr}$ & 37 & 186 & 115 & 39 & 61 & 94 & 105 & 129 & 105 & 73 & 100 \\
\hline $\mathrm{Nb}$ & 2 & 3 & 3 & 3 & 5 & 0 & 3 & 0 & 3 & 2 & 5 \\
\hline $\mathrm{Ba}$ & 359 & 1260 & 594 & 435 & 531 & 1182 & 628 & 892 & 598 & 588 & 564 \\
\hline $\mathrm{La}$ & 5 & 21 & 10 & 7 & 9 & 17 & 11 & 19 & 10 & 8 & 10 \\
\hline $\mathrm{Ce}$ & 15 & 42 & 29 & 14 & 32 & 30 & 26 & 30 & 23 & 18 & 23 \\
\hline
\end{tabular}



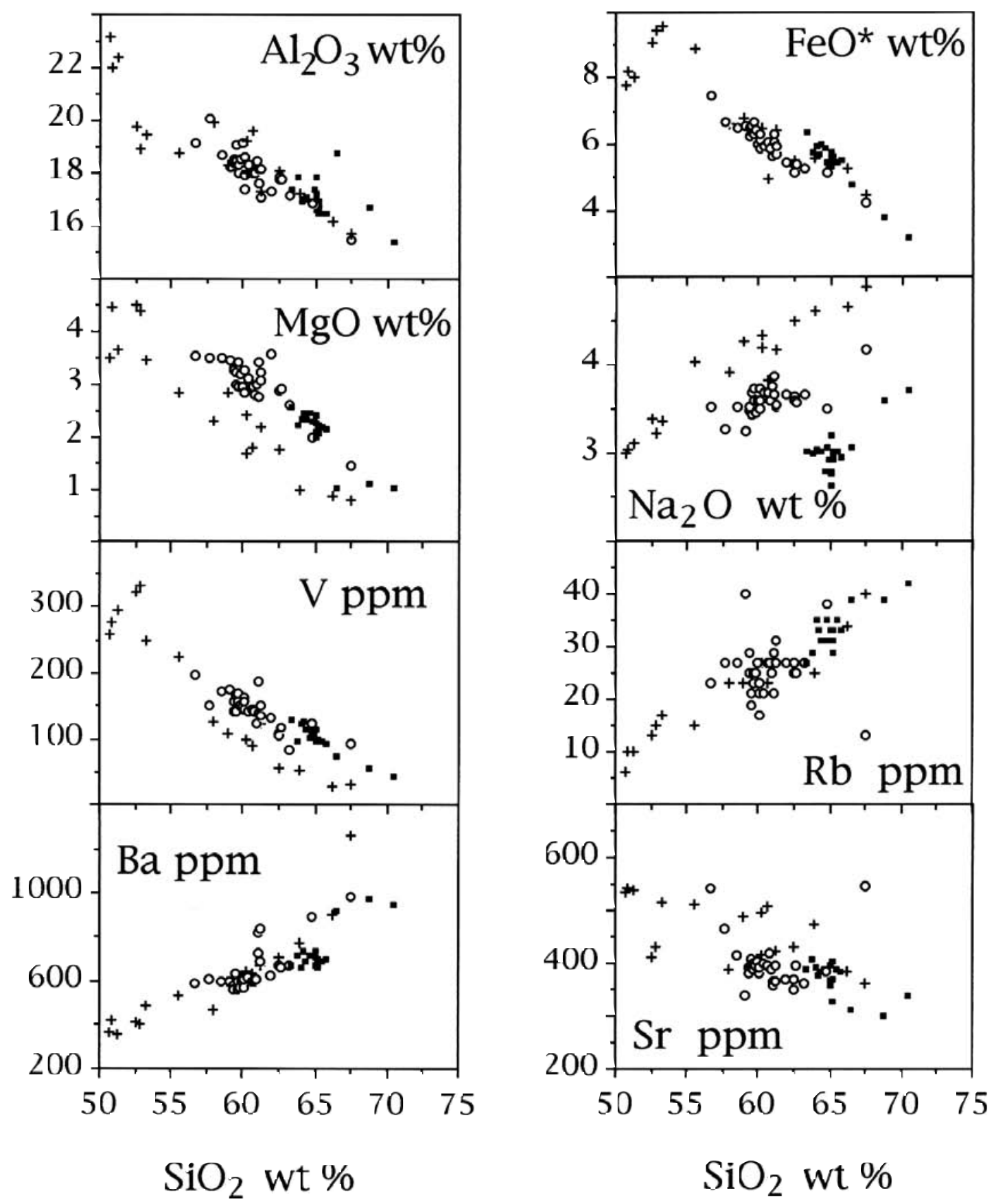

- post-caldera lavas $(\mathrm{CHI})$

- juvenile fragments from pumice falls

+ pre-caldera lavas (CARB) 


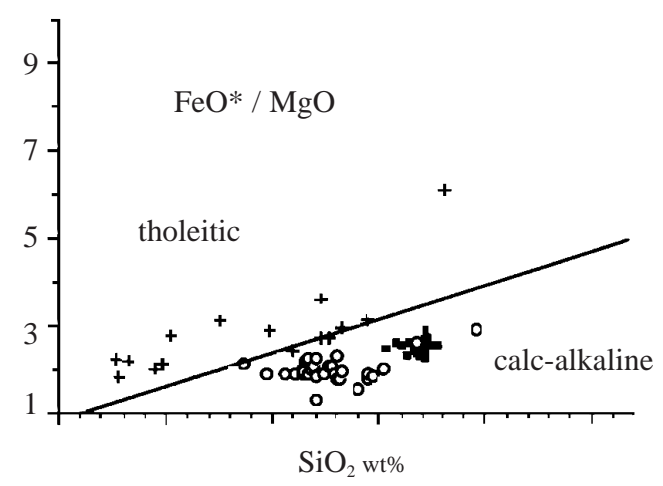

Fig 5: $\mathrm{SiO}_{2}$ vs. $\mathrm{FeO}^{*} / \mathrm{MgO}$. The divisory line between tholeitic and calc-alkaline trends was established by Miyashiro (1974). Symbols as in fig 4.

$\mathrm{Fs}_{35-24}$. They typically show reverse zoning (i.e. $\mathrm{Mg}$-richer rims) and often are jacketed by clinopyroxene. Orthopyroxene is the low-Ca pyroxene in the groundmass, being pigeonite almost completely absent. Augite $\left(\mathrm{Wo}_{42} \mathrm{En}_{42}\right.$ $\mathrm{Fs}_{16}$ ) generally shows normal zoning, but reverse zoning is also observed.

The presence of brown hornblende $(\mathrm{Mg}$ hastingsite), rimmed by a fine grained magnetite and glassy material, is typical of $\mathrm{CHI}$ evolved lavas.

\section{GEOCHEMISTRY}

Taken as a whole, lavas and pyroclastics show a very wide compositional variation (tables 3 and 4). For example, $\mathrm{SiO}_{2}$ ranges from 50 to 72 $\%, \mathrm{Al}_{2} \mathrm{O}_{3}$ from 23 to 16 . Nevertheless, consistent differences among the two groups of lavas and pyroclastics can be traced. Harker-type diagrams (Fig. 4) show that: (i) pre-caldera lavas depict a liquid line of descent driven by the early fractionation of spinel plus olivine and late appearence of Ti-magnetite (Rotolo \& Castorina, in press); (ii) post-caldera lavas are more scattered for almost all elements, clustering at a silica value between 58-62\%; (iii) pumice fragments from the basal fall of the pyroclastic sequence, cluster in the silica rich region, and show a relatively small degree of compositional

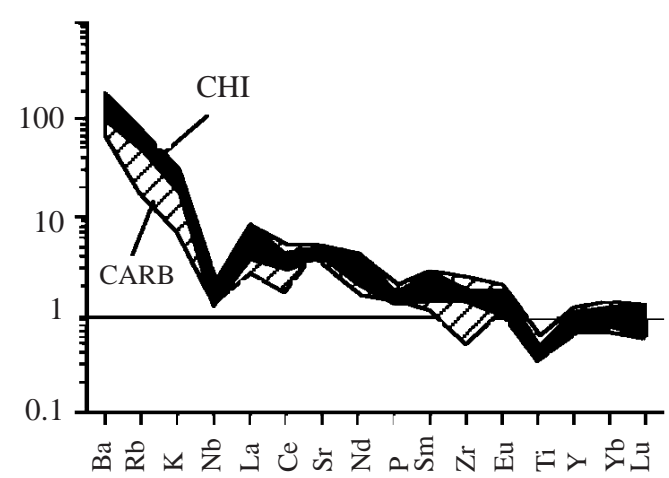

Fig. 6: Spiderdiagram normalized to a N-MORB composition for selected CARB and CHI lavas.

variability; the most marked difference with lavas is in the significantly lower $\mathrm{Na}_{2} \mathrm{O}$ content.

The best distinction between pre- and postcaldera series is shown by the $\mathrm{FeO} * / \mathrm{MgO}$ vs. $\mathrm{SiO}_{2}$ diagram (Miyashiro, 1974): the first shows a transitional to mildly tholeiitic character, while the latter, together with pumice fall deposits, show a typical calc-alkaline one (Fig. 5). Common to all the samples, but specially to pre-caldera lavas, are the very low compatible element abundances (e.g. $\mathrm{Cr}$ and $\mathrm{Ni}<20 \mathrm{ppm}$ ), reflecting the abundant olivine plus pyroxene removal.

CARB series comprises rather evolved tholeiites: Mg\# ranges from 25 to 50. They show a LREE downward concave pattern, Ce negative anomalies, and high $\mathrm{Ba} / \mathrm{La}$ ratios.

$\mathrm{CHI}$ series comprise rocks with $\mathrm{Mg \#}$ ranging from 40 to 60 , and low $\mathrm{TiO}_{2}$ content (0.5-0.8). The chondrite normalized REE pattern shows a slightly higher LREE enrichment compared to CARB $((\mathrm{La} / \mathrm{Yb}) \mathrm{N}=2.8)$ and flat or slightly fractionated HREE patterns.

Negative spikes for $\mathrm{Ti}$ and $\mathrm{P}$ for more evolved samples (Fig. 6) of pre- and postcaldera samples, reflect a crystal fractionation process, particularly the removal of magnetite and apatite. Conversely negative anomalies in $\mathrm{Nb}$, LREE downward concave pattern (not shown), Ce negative anomalies, and high $\mathrm{Ba} / \mathrm{La}$ ratios, are all characters typical of arc magmas, suggesting the signature of the downgoing slab 
Table 4

Representative whole rock XRF analyses of pumice fragments

\begin{tabular}{|c|c|c|c|c|c|}
\hline $\begin{array}{l}\text { Sample } \\
\text { Group }\end{array}$ & $\begin{array}{c}\text { SVN } 52 \\
\text { Basal } \\
\text { Fall }\end{array}$ & $\begin{array}{c}\text { SVN } 54 \\
\text { Basal } \\
\text { Fall }\end{array}$ & $\begin{array}{c}\text { SVN } 110 \\
\text { Basal } \\
\text { Fall }\end{array}$ & $\begin{array}{c}\text { SVN } 145 \\
\text { B1 } \\
\text { Fall }\end{array}$ & $\begin{array}{c}\text { SVN } 152 \\
\text { C } \\
\text { Fall }\end{array}$ \\
\hline $\mathrm{SiO}_{2}$ & 62.16 & 61.09 & 62.16 & 61.78 & 65.82 \\
\hline $\mathrm{TiO} 2$ & 0.54 & 0.54 & 0.51 & 0.58 & 0.47 \\
\hline $\mathrm{Al}_{2} \mathrm{O}_{3}$ & 16.45 & 16.77 & 16.42 & 16.35 & 15.95 \\
\hline FeOtot & 5.78 & 6.16 & 5.51 & 5.90 & 3.79 \\
\hline $\mathrm{MnO}$ & 0.14 & 0.15 & 0.15 & 0.15 & 0.11 \\
\hline $\mathrm{MgO}$ & 2.26 & 2.49 & 1.90 & 2.27 & 1.07 \\
\hline $\mathrm{CaO}$ & 4.91 & 5.09 & 4.83 & 5.31 & 3.34 \\
\hline $\mathrm{Na}_{2} \mathrm{O}$ & 2.90 & 2.91 & 2.64 & 2.92 & 3.43 \\
\hline $\mathrm{K}_{2} \mathrm{O}$ & 1.29 & 1.20 & 1.27 & 1.27 & 1.85 \\
\hline $\mathrm{P}_{2} \mathrm{O}_{5}$ & 0.11 & 0.07 & 0.09 & 0.10 & 0.10 \\
\hline LOI & 3.67 & 3.60 & 4.40 & 3.58 & 4.14 \\
\hline Mg\# & 41.0 & 41.9 & 38.1 & 41.3 & 34.5 \\
\hline $\mathrm{V}$ & 113 & 113 & 94 & 124 & 54 \\
\hline $\mathrm{Cr}$ & 7 & 7 & 5 & 8 & 4 \\
\hline $\mathrm{Co}$ & 18 & 18 & 15 & 18 & 78 \\
\hline $\mathrm{Ni}$ & 2 & 2 & 3 & 3 & 3 \\
\hline $\mathrm{Rb}$ & 31 & 31 & 33 & 35 & 39 \\
\hline $\mathrm{Sr}$ & 384 & 388 & 370 & 393 & 301 \\
\hline $\mathrm{Y}$ & 18 & 19 & 22 & 20 & 20 \\
\hline $\mathrm{Zr}$ & 102 & 94 & 100 & 108 & 134 \\
\hline $\mathrm{Nb}$ & 5 & 2 & 5 & 5 & 5 \\
\hline $\mathrm{Ba}$ & 688 & 670 & 708 & 665 & 975 \\
\hline $\mathrm{La}$ & 9 & 9 & 8 & 10 & 13 \\
\hline $\mathrm{Ce}$ & 24 & 24 & 22 & 26 & 31 \\
\hline
\end{tabular}

(e.g. Carr et al., 1990). The significant $\mathrm{Sr}$ positive anomaly for HABs (Fig. 6), coupled with high $\mathrm{Al}_{2} \mathrm{O}_{3}$ content and positive $\mathrm{Eu}$ anomaly, underline that these rocks suffered plagioclase accumulation.

Taken as a whole, measured strontium isotopic ratios range from 0.70378 to 0.70393 , while neodimium isotopic ratios range from 0.513040 to 0.512971 (mean values: $0.70381 \pm$ $0.000041 \sigma$, and $0.51301 \pm 0.000021 \sigma$, respectively), for a silica content that ranges from 51 to $74 \mathrm{wt} \%$ (Rotolo \& Castorina, in press). The high homogeneity of ${ }^{87} \mathrm{Sr} /{ }^{86} \mathrm{Sr}$ and ${ }^{143} \mathrm{Nd} /{ }^{144} \mathrm{Nd}$ ratios makes impossible a distinction of the pre- and post-caldera lavas.

\section{CONCLUDING REMARKS}

A three-stage evolution for the San Vicente volcanic complex, based on geological and geochemical evidences, is proposed: (i) a first effusive phase during which mildly tholeiitic to transitional lavas were emitted, building up the La Carbonera complex. Presently, La Carbonera lavas outcrop in annular arrangement, in the western sector of the San Vicente volcanic complex; (ii) a pyroclastic phase, leading to the collapse of the edifice and to the formation of the La Carbonera caldera; (iii) the post-caldera phase, during which the actual edifice - mainly composed of andesitic lavas - was built.

The overall relative homogeneity of $\mathrm{Sr}$ and $\mathrm{Nd}$ ratios, both in pre- and post-caldera lavas, indicate a well-mixed magma and the dominance of low pressure fractional crystallization processes over others; they indicate also that they share a common mantle source (Rotolo \& Castorina, in press). Chemical patterns and mass balance calculations showed that crystal fractionation was the principal evolutive process, while the slight isotopic and elemental variations, suggest that crystal fractionation coupled with assimilation cannot be invoked (Rotolo \& Castorina, in press). The relative offset of $\mathrm{Sr}$ relative to $\mathrm{Nd}$ is considered to be due to the contribution of pelagic terrigenous sediments of the subducted slab and the interaction of slab-derived hydrous melts with the mantle wedge.

The event that triggered the explosive phase at the end of CARB cycle, is yet uncertain. Magma mixing is often invoked as an important triggering mechanism (e.g. Sparks et al., 1977), but petrographic data supporting mixing with more primitive magmas (e.g. reverse zoning in pyroxene and plagioclase, sieved rims in some plagioclase megacrystals filled with glass), are restricted to few post-caldera lavas. Furthermore the lack of truly hybrid rocks and the lack of abrupt increase in compatible elements, suggests a minor role played by this process. We speculate that the primary control on triggering the explosive eruption could have been structural, 
particularly related to the extensional E-W fault system created by the opening of the Central Graben (late Pliocene). Faults may have intersected the pre-caldera magma chamber, inducing thus rapid magma depressurization and volatiles exsolution.

The renewal of volcanic activity after the plinian phase is characterized by different petrographical and geochemical patterns as a result of a thorough modification of the feeding system of the volcano. Should this model be verified in other areas of El Salvador, it could be useful to explain the complex history of this sector of the Middle American Arc, where active volcanoes are locate along the Central Graben axis.

From the point of view of geothermal exploration, our findings stress the presence of low-pressure evolutive processes, that is, the presence of a superficial, high-volume magma chamber. The presence of an ancient hydrothermal system is suggested by the propylitic hydrothermal alteration in lithic fragments from the pyroclastic sequence. Similar mineralogical assemblages were found at the bottom of the SV-1 geothermal well (CEL, 1992) - drilled on the northern slopes of the San Vicente cone - where a highly permeable layer was intersected.

\section{ACKNOLEDGEMENTS}

The Salvadorian state agency for electric power, Comision Ejecutiva Hidroelectrica del Rio Lempa (CEL), Ing. Renato Jacobo, Nelson Heskee, Roberto Rugamas and others at CEL are warmly thanked for the valuable cooperation and assistance with logistical support during field work in El Salvador. Dr. Siegfried Kussmaul is acknowledged for helpful editorial comments.

\section{REFERENCES}

AIUPPA, A., CARAPEZZA, M.L. \& PARELLO, F., 1997: Fluid geochemistry of the San Vicente geothermal field (El Salvador). - Geothermics, 26: 83-97.
BARBERI, F., ROTOLO, S.G., \& AIUPPA, A., 1995: Petrology of Chichontepeque volcano (El Salvador). - Periodico di Mineralogia, 64: 89-91.

CARR, M.J. MAYFIELD, D.G. \& WALKER, J.A. , 1981: Relation of lava compositions to volcano size and structure in El Salvador. - J. Volc. Geoth. Res. 10: 35-48.

CARR, M.J., 1976: Underthrusting and Quaternary faulting in Central America. Geol. Soc. Am. Bull. 84: 2917-2930.

CARR, M.J. \& Stoiber R.E., 1977: Geologic setting of some destructive earthquakes in Central America. - Geol. Soc.Am. Bull. 88: 151-156.

CARR, M.J., Mayfield, D.G.\& Walker, J.A., 1981: Relation of lava compositions to volcano size and structure in El Salvador. - J. Volc. Geoth. Res. 10: 35-48.

CARR, M.J., Feigenson, M.D.\& Bennett, E.A., 1990: Incompatible element and isotopic evidence for tectonic control of source mixing and melt extraction along the Central American arc. - Contrib. Mineral. Petrol.105: 369-380.

CEL (Comision Ejecutiva Hidroelectrica del Rio Lempa), 1992: Informe de prefactibilidad del campo geotermico de San Vicente. (unpublished report) 1-67. San Salvador.

FRANZINI, M., LEONI, L. \& SAITTA, M., 1975: Revisione di una metodologia analitica per fluorescenza-X, basata sulla correzione completa degli effetti matrice.Rend. Soc. Ital. di Mineral. e Petrol. 31: 65-378.

HART, W.J.E. \& STEEN-MCINTYRE, V., 1983: Tierra Blanca Joven tephra from the A.D. 260 eruption of Ilopango. - In The Zapotitn Valley of El Salvador. 
Archaelogy and Volcanism in Central America. Ed. Payson D. Sheets. pp. 1443. University of Texas Press, Austin.

MEYER J., 1967: Geology of the Ahuachapan Area, Western El Salvador, Central America. - Tulane Stud. in Geol. 5 : 195215, New Orleans.

MEYER-ABICH H., 1956: Los Volcanes activos do Guatemala y El Salvador. - Anales Serv. Geol. Nacl. El Salvador, Bd. 3: 4962.

MIYASHIRO, A., 1974: Volcanic rock series in island arcs and active continental margins. - Am. J. Sci. 274: 321-355.

PICHLER, H. \& WEYL, R., 1973: Petrochemical aspects of Central American magmatism. - Geol. Rundsch. 62: 357-396.
ROTOLO, S.G. \& CASTORINA, F., 1998: Transition from mildly-tholeiitic to a calcalkaline suite: the case of Chichontepec volcanic centre, El Salvador, Central America. - J. Volcan. Geoth. Res. 84.

SPARKS, S.R.J., WILSON, L \& SIGURDSONN, H., 1977: Magma mixing: a mechanism for triggering acid explosive eruptions. - Nature, 267: 315318.

WIESEMANN, G., 1975: Remarks on the geologic structure of the republic of El Salvador, Central America. - Mitt. Geol. Paleontol. Inst. Univ. Hamburg, 44: 557-574.

WILLIAMS, H. \& MEYER-ABICH, H., 1955: Volcanism in the southern part of El Salvador. - Univ. Calif. Publ. Geol. Sci. 32(1): 1-64, Berkeley and Los Angeles. 